\title{
Article \\ Biogenic Synthesis of Iron Oxide Nanoparticles Using Enterococcus faecalis: Adsorption of Hexavalent Chromium from Aqueous Solution and In Vitro Cytotoxicity Analysis
}

\author{
Melvin S. Samuel ${ }^{1}$, Saptashwa Datta ${ }^{2} \mathbb{D}$, Narendhar Chandrasekar $^{3} \mathbb{D}$, Ramachandran Balaji $^{4}$, \\ Ethiraj Selvarajan $2, * \mathbb{D}$ and Srikanth Vuppala $5, *$ (D) \\ 1 School of Environmental Science and Engineering, Indian Institute of Technology, \\ Kharagpur 21302, West Bengal, India; melvinsamuel08@gmail.com \\ 2 Department of Genetic Engineering, School of Bioengineering, SRM Institute of Science and Technology, \\ Kattankulathur, Chennai 603203, Tamil Nadu, India; saptashwada.abc@gmail.com \\ 3 Department of Nanoscience and Technology, Sri Ramakrishna Engineering College, \\ Coimbatore 641022, Tamil Nadu, India; narendhar.nano@gmail.com \\ 4 Department of Chemical Engineering and Biotechnology, National Taipei University of Technology, \\ Taipei 10608, Taiwan; balajiyashik@gmail.com \\ 5 Department of Civil and Environmental Engineering, Politecnico di Milano, Piazza Leonardo da Vinci, \\ 3220133 Milan, Italy \\ * Correspondence: selrajan@gmail.com (E.S.); srikanth.vuppala@uniroma1.it (S.V.)
}

\section{check for} updates

Citation: Samuel, M.S.; Datta, S.; Chandrasekar, N.; Balaji, R.; Selvarajan, E.; Vuppala, S. Biogenic Synthesis of Iron Oxide Nanoparticles Using Enterococcus faecalis: Adsorption of Hexavalent Chromium from Aqueous Solution and In Vitro Cytotoxicity Analysis. Nanomaterials 2021, 11, 3290. https://doi.org/ $10.3390 /$ nano11123290

Academic Editor: Giuliana Taglieri

Received: 7 November 2021

Accepted: 27 November 2021

Published: 3 December 2021

Publisher's Note: MDPI stays neutral with regard to jurisdictional claims in published maps and institutional affiliations.

Copyright: (c) 2021 by the authors. Licensee MDPI, Basel, Switzerland. This article is an open access article distributed under the terms and conditions of the Creative Commons Attribution (CC BY) license (https:// creativecommons.org/licenses/by/ $4.0 /)$.

\begin{abstract}
The biological synthesis of nanoparticles is emerging as a potential method for nanoparticle synthesis due to its non-toxicity and simplicity. In the present study, a bacterium resistant to heavy metals was isolated from a metal-contaminated site and we aimed to report the synthesis of $\mathrm{Fe}_{3} \mathrm{O}_{4}$ nanoparticles via co-precipitation using bacterial exopolysaccharides (EPS) derived from Enterococcus faecalis_RMSN6 strains. A three-variable Box-Behnken design was used for determining the optimal conditions of the $\mathrm{Fe}_{3} \mathrm{O}_{4} \mathrm{NPs}$ synthesis process. The synthesized $\mathrm{Fe}_{3} \mathrm{O}_{4} \mathrm{NPs}$ were thoroughly characterized through multiple analytical techniques such as XRD, UV-Visible spectroscopy, FTIR spectroscopy and finally SEM analysis to understand the surface morphology. $\mathrm{Fe}_{3} \mathrm{O}_{4} \mathrm{NPs}$ were then probed for the $\mathrm{Cr}(\mathrm{VI})$ ion adsorption studies. The important parameters such as optimization of initial concentration of $\mathrm{Cr}(\mathrm{VI})$ ions, effects of contact time, $\mathrm{pH}$ of the solution and contact time on quantity of $\mathrm{Cr}(\mathrm{VI})$ adsorbed were studied in detail. The maximum adsorption capacity of the nanoparticles was found to be $98.03 \mathrm{mg} / \mathrm{g}$. The nanoparticles could retain up to $73 \%$ of their efficiency of chromium removal for up to 5 cycles. Additionally, prepared $\mathrm{Fe}_{3} \mathrm{O}_{4} \mathrm{NPs}$ in the concentration were subjected to cytotoxicity studies using an MTT assay. The investigations using $\mathrm{Fe}_{3} \mathrm{O}_{4} \mathrm{NPs}$ displayed a substantial dose-dependent effect on the A594 cells. The research elucidates that the $\mathrm{Fe}_{3} \mathrm{O}_{4} \mathrm{NPs}$ synthesized from EPS of E. faecalis_RMSN6 can be used for the removal of heavy metal contaminants from wastewater.
\end{abstract}

Keywords: A549 cells; chromium (VI); E. faecalis_RMSN6; exopolysaccharide; $\mathrm{Fe}_{3} \mathrm{O}_{4}$

\section{Introduction}

Magnetic nanoparticles play a critical role in various fields such as areas of bionanotechnology, drug delivery and biosorption applications [1-3]. To date, only dextrancoupled iron oxide nanoparticles are permitted by the U.S. Food and Drug Administration (FDA) [4]. Iron oxide nanoparticles have applications in various fields such as tissue engineering, immunoassay technology, cell separation, drug delivery, and heavy metal removal [5-8]. In recent years, a lot of research has been carried out to classify different types of iron oxide nanoparticles, especially the conjugates such as magnet viz, maghemite $\left(\mathrm{Fe}_{2} \mathrm{O}_{3}\right)$ or magnetite $\left(\mathrm{Fe}_{3} \mathrm{O}_{4}\right)$, among which magnetite has been found to be highly biocompatible [9]. Magnetite is a magnetic iron oxide with an inverse cubic spinel structure along with oxygen, forming a closed FCC bundle where Fe cations occupy the intestinal 
tetrahedral and octahedral positions [10]. Magnetite has a widespread application in the field of biomedical viz. (a) cellular therapy, (b) tissue repair, (c) drug delivery, (d) magnetic resonance imaging, (d) hyperthermia, etc. [11].

Magnetic iron oxide nanoparticles can be synthesized using various physical, chemical and biological methods [12]. Physical methods include the usage of gas-phase deposition and electron-beam lithography [13-15]. However, these techniques suffer from the limitation of controlling the size of the particle. The chemical method includes sleet of $\mathrm{Fe}^{2+}$ and $\mathrm{Fe}^{3+}$ aqueous salt solution by adding a base and is more efficient, with excellent control over the size and shape of the nanoparticle [16]. The conventional method involves adding a base to an aqueous solution mixture of $\mathrm{Fe}^{2+}$ and $\mathrm{Fe}^{3+}$ chloride ions at a molar ratio of 1:2. An alternative approach to produce the magnetic nanoparticle is by bacterial mediated synthesis [17]. Various types of nanoparticles have been synthesized using bacterial mediated biosynthesis such as zinc oxide, magnesium oxide nanoparticles, iron oxide nanoparticles etc. This is effective mainly due to its low cost, control over magnetic property, control over size and increased biocompatibility. However, the major drawback is the long time required for synthesis when compared to the other conventional methods [18]. Papers have previously reported bacterial synthesis of iron oxide nanoparticle-based on the redox properties in Mycobacterium paratuberculosis, Shewanella oneidensis and Geothrix fermentans, which could reduce $\mathrm{Fe}^{3+}$ by redox compounds, to serve as an electron shuttle between the microbe and the insoluble iron substrate [19-21].

Heavy metals and synthetic organic dyes are the important raw materials predominantly used in large-scale production of various drugs, textile materials and leathers [22]. It is worth mentioning that $10-15 \%$ of heavy metals and dye molecules are exerted into the environment during the treatment process [23]. Hexavalent $\mathrm{Cr}(\mathrm{VI})$ and trivalent $\mathrm{Cr}(\mathrm{III})$ are the most stable and prevalent forms of chromium (oxidation states 2 to +6 ). $\mathrm{Cr}(\mathrm{VI})$ chemistry is strongly influenced by the $\mathrm{pH}$ and concentration of the solution, and it usually exists in the anionic form as $\mathrm{Cr}_{2} \mathrm{O}_{7}{ }^{2-}$ (dichromate), $\mathrm{HCrO}_{4}{ }^{-}$(hydrogen chromate), or $\mathrm{CrO}_{4}{ }^{2-}$ (chromate), depending on $\mathrm{pH}$ and concentration. $\mathrm{H}_{2} \mathrm{CrO}_{4}$ is the dominating species at $\mathrm{pH}$ values below 1 (chromic acid) and around 2 in acidic media. Dichromate $\left(\mathrm{Cr}_{2} \mathrm{O}_{7}{ }^{2-}\right)$ ions are the most common type of $\mathrm{Cr}(\mathrm{VI}) . \mathrm{Cr}_{2} \mathrm{O}_{7}{ }^{2-}$ and $\mathrm{HCrO}_{4}{ }^{-}$ions are in equilibrium between $\mathrm{pH} 2$ and 6 , and $\mathrm{Cr}_{2} \mathrm{O}_{7}{ }^{2-}$ and $\mathrm{HCrO}_{4}$ ions are prominent as chromate anion in alkaline conditions $(\mathrm{pH}>8)$. The vital issues arising due to these pollutants are very low biodegradability and less chemical stability in environmental aquatic systems [24]. In such a way, chromium is one of the most available elements on the globe, and its undeniable presence in water bodies and inland has escalated beyond its sustainable limit in recent decades [25]. The National Institute of Occupational Safety and Health (NIOSH), Washington, D.C, USA has listed chromate compounds as one of the leading causes of occupational lung cancer, and the U.S. Environmental Protection Agency (EPA) and the International Agency for Research on Cancer (IARC) have classified chromium as a human carcinogen, making $\mathrm{Cr}(\mathrm{VI})$ one of 33 compounds currently listed as posing the greatest potential health threat in urban areas. The chromium is present in two different modes such as chromium $\mathrm{Cr}$ (III) and $\mathrm{Cr}$ (IV) [26,27]. When human beings are in contact with chromium, it often leads to severe skin reactions and cancer in some cases. The possible dangers of $\mathrm{Cr}(\mathrm{VI})$ exposure by intake of drinking water have recently received more attention. Several short-term in vivo experiments conclusively demonstrated that $\mathrm{Cr}(\mathrm{VI})$ genotoxic 's potential is dose-dependent, with indications of a substantial threshold effect due to extracellular detoxification (by reduction to $\mathrm{Cr}(\mathrm{III})$ ) prior to absorption by peripheral organs and tissues [28]. The toxic effect of $\mathrm{Cr}(\mathrm{IV})$ is way higher than trivalent $\mathrm{Cr}$ (III) ions. Therefore, the $\mathrm{Cr}(\mathrm{IV})$ is actively categorized as a group ' $\mathrm{A}$ ' carcinogen as it shows teratogenic, carcinogenic and mutagenic traits. The main sources of $\mathrm{Cr}(\mathrm{IV})$ that release toxins to aquatic systems are wood-stocking industries, battery fabrication, dye-based industries, leather tanning, electroplating factories and metal polishing industries [29,30]. Currently, industries have commenced discovering alternate ways for treating $\mathrm{Cr}(\mathrm{IV})$ comprising wastewaters but at present, available Cr(IV) treatments from wastewaters were found to 
display reduced competence at lower concentrations. Although conventional methods viz. chemical reduction, electrochemical, ion-exchange and dialysis methods are being used for removing $\mathrm{Cr}(\mathrm{IV})$ ions from wastewater, they are relatively extortionate, inefficacious at lower concentrations and also lead to environmental difficulties of waste disposal [31-33]. Recently, researchers established several variegate materials that are extensively utilized for the removal of heavy metals, such as activated carbon [34], carbon nanotubes [35], polymers [36], resins [37], graphene materials [38]. Amongst all the materials, the Febased magnetic nanomaterials are widely preferred due to their alluring properties such as high specific surface area, simple synthesis process and no formation of by-products as a secondary pollutant [39]. Many iron oxide composite nano and micromaterials have been designed over the years for the remediation of various pollutants including heavy metals [40]. Various adsorbent materials such as mussel-inspired adsorbents, magnetic nano-adsorbents, and magnetic hydrogels have been utilized for the removal of pollutants from wastewater [41-45].

Microbial exopolysaccharides (EPSs) are classified as biopolymers. The EPSs are secreted in the extracellular medium through the microbial cells, which creates a slime-like substance clinging to the surface of the cells $[46,47]$. These formed compounds might be either a soluble or insoluble polymer that are released outside the cells and later to the environment [48]. Therefore, the synthesis of EPS is very significant for the microbial cells as it plays an important role in their survival [49]. Cell defense, connection to solid surfaces, cell aggregation, and cell-cell interactions are among these roles. EPS may be formed by different classes of microorganisms such as microbes, cyanobacteria, fungi and yeasts, and microalgae [50]. This investigation emphasizes the capacity of bacterial EPSs to play as reducing and stabilizing compounds during the bio-mediated production of metal nanoparticles for multifunctional application (heavy metal removal and cytotoxicity studies). We used a new bacterium, E. faecalis_RMSN6: (i) to extract EPS from E. faecalis, (ii) synthesis of highly stable iron oxide nanoparticle $\left(\mathrm{Fe}_{3} \mathrm{O}_{4} \mathrm{NPs}\right)$ by coating EPS on $\mathrm{Fe}_{3} \mathrm{O}_{4} \mathrm{NPs}$ (iii) $\mathrm{Fe}_{3} \mathrm{O}_{4}$ NPs was characterized using different types of analytical instruments, (iv) to evaluate synthesized $\mathrm{Fe}_{3} \mathrm{O}_{4} \mathrm{NPs}$ as adsorbents to remove $\mathrm{Cr}(\mathrm{VI})$ metal ions from an aqueous solution, and in vitro toxicity analysis of synthesized $\mathrm{Fe}_{3} \mathrm{O}_{4}$ NPs using EPS.

\section{Materials and Methods}

\subsection{Materials}

The precursors and the reagents were obtained from Sigma-Aldrich, Mumbai, Maharashtra, India. All the chemicals involved in the research were utilized without any further purification. The MRS agar and MRS broth were bought from HiMedia Laboratories Pvt. Ltd., Mumbai, Maharashtra, India.

\subsection{Isolation, Screening, and Identification of Enterococcus faecalis_RMSN6 and Biosynthesis of $\mathrm{Fe}_{3} \mathrm{O}_{4}$ Nanoparticle}

Samples were isolated from a metal-contaminated site from Vellore, Tamil Nadu in India. The isolated strains were screened for resistance against metals using the agar diffusion method. Briefly, plates comprising $20 \mathrm{~mL}$ tris-minimal agar medium were supplemented with varying concentrations $(0,10,25,50$ and $100 \mathrm{mg} / \mathrm{L})$ of chromium, copper, cadmium and lead. One of the bacterial samples showed resistance to the heavy metals, and bacteria were isolated and grown in MRS broth at $37{ }^{\circ} \mathrm{C}$ for $48 \mathrm{~h}$ [50]. The 16s RNA sequence of the bacteria was then sequenced using Illumina sequencing. The neighbour-joining phylogenetic tree of 16s rRNA gene sequence of bacterial strain Enterococcus faecalis_RMSN6 and most closely related species are shown in Figure $\mathrm{S} 1$ and the assembled Sequence for E. faecalis_RMSN6 (Figure S2). Primer details and PCR protocol are shown in Table S1. The bacterial isolate E. faecalis_RMSN6 was inoculated into a $250 \mathrm{~mL}$ Erlenmeyer flask containing $100 \mathrm{~mL}$ MRS broth in sterile condition at $\mathrm{pH} 7$ and followed by incubation at $37^{\circ} \mathrm{C}$ for 2 days. After the incubation period, the culture was centrifuged at $8000 \mathrm{rpm}$ for $10 \mathrm{~min}$ at $4{ }^{\circ} \mathrm{C}$. To the cell-free supernatant made up of EPS, $0.1 \mathrm{M}$ iron chloride tetrahydrate 
$\left(\mathrm{FeCl}_{2} \cdot 4 \mathrm{H}_{2} \mathrm{O}\right)$ and $0.2 \mathrm{M}$ iron chloride hexahydrate $\left(\mathrm{FeCl}_{3} \cdot 6 \mathrm{H}_{2} \mathrm{O}\right)$ were added into the flask. The flasks were then incubated in dark at room temperature, resulting in a dark brown color indicating the formation of $\mathrm{Fe}_{3} \mathrm{O}_{4} \mathrm{NPs}$. To find out the effect of temperature, $\mathrm{pH}$ and incubation time of the nanoparticle formation, a range of temperatures $(22,27,32,37$ and $\left.55^{\circ} \mathrm{C}\right), \mathrm{pH}(2.0-7.0)$ and incubation times $(20-120 \mathrm{~h})$ was chosen for optimizing the nanoparticle synthesis.

\subsection{Box-Behnken Design (BBD)}

The investigative setup was constructed using a Box-Behnken design (BBD) for the analysis [51-53]. This model is ideal for quadratic surface fitting and also for the optimization process. The BBD is typically utilized for analyzing the effect of 3 independent variables ranging viz. $\mathrm{pH}(\mathrm{X} 1)(2.0-7.0)$, temperature factor $(\mathrm{X} 2)\left(22-55^{\circ} \mathrm{C}\right)$ and finally, duration of incubation (X3) (20-120 h) concerning the yield of the nanoparticle. The design Expert software was used to analyze the obtained investigative data (version 9, stat-Ease, Inc., Minneapolis, MN, USA).

\subsection{Material Characterization}

The UV-Vis spectrophotometer supplied from Sulpeco, India was used to measuring the absorption of bio-synthesized $\mathrm{Fe}_{3} \mathrm{O}_{4}$ NPs. Similarly, the FT-IR spectra for $\mathrm{Fe}_{3} \mathrm{O}_{4} \mathrm{NPs}$ were performed in IR affinity-1, Shimadzu, Japan to analyze the functional groups. The Phillips PW 1830 instrument (Sulpeco, India) equipped with $\mathrm{CuK} \alpha=1.54 \AA$ (operating conditions: $40 \mathrm{kV}$ and $30 \mathrm{~mA}$ ) was probed for obtaining the XRD spectra of bio-synthesized $\mathrm{Fe}_{3} \mathrm{O}_{4} \mathrm{NPs}$. The surface roughness of the $\mathrm{Fe}_{3} \mathrm{O}_{4}$ NPs was analyzed using an AFM instrument supplied by Nano surf AG (Gräubernstrasse, Liestal, Switzerland), Switzerland. The surface morphology and chemical composition of $\mathrm{Fe}_{3} \mathrm{O}_{4}$ NPs were studied using scanning electron microscopy from Bruker (Billerica, MA, USA). The Nanoparticle Analyzer SZ-100, Horiba Scientific (Miyanohigashi, Kisshoin, Minami-ku Kyoto, Japan) is utilized to understand the particle size and zeta potential of $\mathrm{Fe}_{3} \mathrm{O}_{4}$ NPs.

\subsection{Adsorption Investigation}

The experiments for adsorption of $\mathrm{Cr}(\mathrm{IV})$ using bio-synthesized $\mathrm{Fe}_{3} \mathrm{O}_{4}$ nanoparticles were performed in batches. The vital experimental parameters such as the influence of $\mathrm{pH}(1-9)$, contact time (0-600 $\mathrm{min})$, the dosage of adsorbent (concentration 0.5-2.0 g/L) were investigated. The $20 \mathrm{~mL}$ reaction flask with $\mathrm{Cr}(\mathrm{IV})$ ion solution at varying concentrations ranging from 10-125 mg/L was made using the standard addition method for the adsorption experiments. The $\mathrm{pH}$ value of the standard solution was optimized to $\mathrm{pH} 2$ with the $\mathrm{Fe}_{3} \mathrm{O}_{4}$ nanoparticle concentration of $0.5 \mathrm{~g} / \mathrm{L}$. Furthermore, the $\mathrm{Fe}_{3} \mathrm{O}_{4}$ nanoparticles were filtered well and the concentrations of $\mathrm{Cr}(\mathrm{IV})$ were calibrated using the 1,5-diphenylcarbazide method. The RMSE: root means square error Equations (2) and (3).

$$
\begin{aligned}
& q_{e}=\frac{C_{o}-C_{f}}{M} \times V \\
& R_{2}=1-\frac{\sum_{n=1}^{n}\left(Y_{\text {pred }, i}-y_{\text {exp. } . i}\right)^{2}}{\sum_{n=1}^{n}\left(Y_{\text {pred }, i}-y_{\text {exp } . i}\right)^{2}} \\
& R M S E=\frac{1}{n-1} \sqrt{\sum_{n=1}^{n}\left(Y_{\text {pred }, i}-y_{\text {exp.i }}\right)^{2}}
\end{aligned}
$$

in the equations, the $C_{o}$ and $C_{f}$ correspond to the initial and equilibrium concentration of $\mathrm{Cr}(\mathrm{IV})$. The $\mathrm{V}(\mathrm{L})$ refers to the volume of the solution. The $\mathrm{m}(\mathrm{g})$ is for the adsorbent weight and consequently, $q_{e}(\mathrm{mg} / \mathrm{g})$ indicates the adsorption capacity of the adsorbent.

\subsection{MTT Assay Using A549 Cell Lines}

The Lung cell lines (A549) were cultured in Dulbecco's altered eagle medium reinforced with $10 \%$ Fetal Bovine Serum and 1\% penicillin. An MTT assay was performed 
using A549 cell lines with varying concentrations of $\mathrm{Fe}_{3} \mathrm{O}_{4} \mathrm{NPs}$ in a range of 10-200 $\mu \mathrm{g} / \mathrm{L}$. The absorbance values of the 96-well plate was quantified using ELISA. All the experiments were performed in triplicates. The IC50 value of the nanoparticles was calculated using GraphPad Prism 9.1.0 software, San Diego, CA, USA [50].

\subsection{Statistical Analysis}

All statistical analysis was done using GraphPad Prism 9.1.0 software, San Diego, CA, USA.

\section{Results and Discussion}

\subsection{Synthesis and Physical Characterizations of Bio-Synthesized $\mathrm{Fe}_{3} \mathrm{O}_{4}$ Nanoparticles}

In our study, we report the synthesis of $\mathrm{Fe}_{3} \mathrm{O}_{4} \mathrm{NPs}$ by means of a biological method using iron chloride solution mixed with the culture supernatant of E.faecalis_RMSN6. When the colorless solution in the synthesis turned darkish brown, it confirmed the formation of $\mathrm{Fe}_{3} \mathrm{O}_{4}$ NPs. The color shift from colorless to brown happened due to the surface plasmon resonance (SPR) property of the material. The biosynthesis of $\mathrm{Fe}_{3} \mathrm{O}_{4} \mathrm{NPs}$ through $E$. faecalis_RMSN6 also combined the physical synthesis process. The important advantages of the microbial synthesis technique are high yield, low cost and superior reproducibility. B. subtilis was used to isolate the Aspergillus niger YESM 1 from the $\mathrm{Fe}_{3} \mathrm{O}_{4} \mathrm{NPs}$. Then, the ferric oxide solution was combined with the supernatant of B. subtilis [54]. Finally, the formation of $\mathrm{Fe}_{3} \mathrm{O}_{4}$ NPs was confirmed by the change in color. The brick color indicates the unreduced $\mathrm{Fe}_{3} \mathrm{O}_{4}$, and the dark brown color refers to the $\mathrm{Fe}_{3} \mathrm{O}_{4} \mathrm{NPs}$ [55].

The UV-vis spectrophotometry analysis confirmed the formation of $\mathrm{Fe}_{3} \mathrm{O}_{4} \mathrm{NPs}$, which gives rise to the surface plasmon resonance (SPR) adsorption band. The broad peak at 268 nm indicates the synthesis of $\mathrm{Fe}_{3} \mathrm{O}_{4}$ NPs. The adsorption peak is not stable; it can shift due to $\mathrm{pH}$, incubation time, temperature, etc. The FTIR spectra for the biosynthesized $\mathrm{Fe}_{3} \mathrm{O}_{4}$ NPs are shown in Figure 1a. The peak at 2949, 2916 and $2837 \mathrm{~cm}^{-1}$ denote -H-C-H- and $\mathrm{C}=\mathrm{O}$ stretching. The corresponding peaks at 1585,1450 and $1359 \mathrm{~cm}^{-1}$ are assigned to amide groups and -CN- stretching amines; the peak at $1107 \mathrm{~cm}^{-1}$ is for the C-O stretch, and the peak arises due to the covalent linking of ester or ether groups to the nanoparticle. These results demonstrated that functional groups present in the EPS had successfully modified $\mathrm{Fe}_{3} \mathrm{O}_{4}$. The peaks at $875 \mathrm{~cm}^{-1}$ and $845 \mathrm{~cm}^{-1}$ are for the iron oxide. The X-ray diffraction pattern of the $\mathrm{Fe}_{3} \mathrm{O}_{4}$ NPs is shown in Figure 1b. The characteristic diffraction peaks arise at $2 \theta: 30.26,35.56,43.32,53.79,57.32$ and 62.98 . They are respectively belonging to (220), (311), (400), (422), (511) and (440) planes. These characteristic peaks are in agreement with standard diffraction data JCPDS: 39-1346 and correspond to face-centered cubic (fcc) symmetry [56].

The SEM images confirm the presence of irregularly shaped particles (Figure 2). The particles can be seen to be coated in bio-molecular groups that lead to clumping of the nanoparticles (Figure 2). The SEM images of the $\mathrm{Fe}_{3} \mathrm{O}_{4}$ NPs were cubical, hexagonal, brick and irregular in shape (Figure 2a). The Figure 2a insert shows the EDX spectrum of $\mathrm{Fe}_{3} \mathrm{O}_{4}$ NPs synthesized using cell-free supernatant of E. faecalis_RMSN6; the Fe adsorption peak appears approximately at $0.7,6.5$ and $7 \mathrm{KeV}$ due to surface plasmon resonance. In the Figure $2 \mathrm{~b}$ insert, the EDX spectrum of $\mathrm{Fe}_{3} \mathrm{O}_{4}$ NPs after adsorption shows peaks approximately at $0.7,6.5,7.5$ for Fe and $0.5,5.3$ and 5.9 for $\mathrm{Cr}(\mathrm{IV})$. Therefore, adsorption of $\mathrm{Cr}(\mathrm{IV})$ onto $\mathrm{Fe}_{3} \mathrm{O}_{4}$ NPs was confirmed by the EDX spectrum. The TEM images confirm the morphology of $\mathrm{Fe}_{3} \mathrm{O}_{4}$ nanoparticles, which is shown in Figure 2c,d. The $\mathrm{Fe}_{3} \mathrm{O}_{4}$ nanoparticles display a regular external surface, with wrinkles at center and smooth edges. Furthermore, using dynamic light scattering (DLS) analysis, the particle size of the $\mathrm{Fe}_{3} \mathrm{O}_{4}$ NPs was determined to be $15.4 \mathrm{~nm}$. The $\mathrm{Fe}_{3} \mathrm{O}_{4} \mathrm{NPs}$ stability was analyzed using zeta potential. The obtained zeta potential value was $-29.6 \mathrm{mV}$. The value of zeta potential is directly proportional to the particle stability. The analysis showed that the stability of the synthesized iron oxide nanoparticle was higher. 

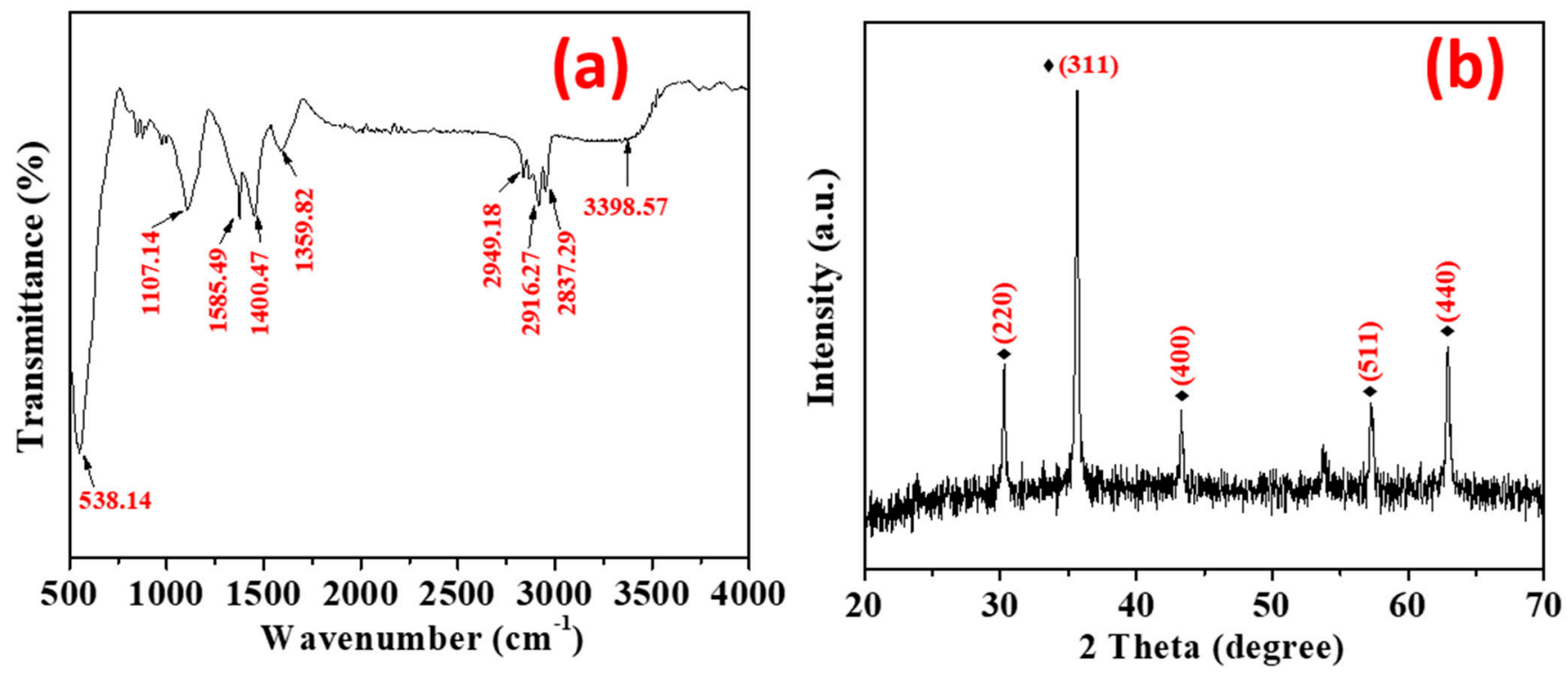

Figure 1. (a) FT-IR spectra of $\mathrm{Fe}_{3} \mathrm{O}_{4}$ NPs, (b) XRD patterns of $\mathrm{Fe}_{3} \mathrm{O}_{4}$ NPs.

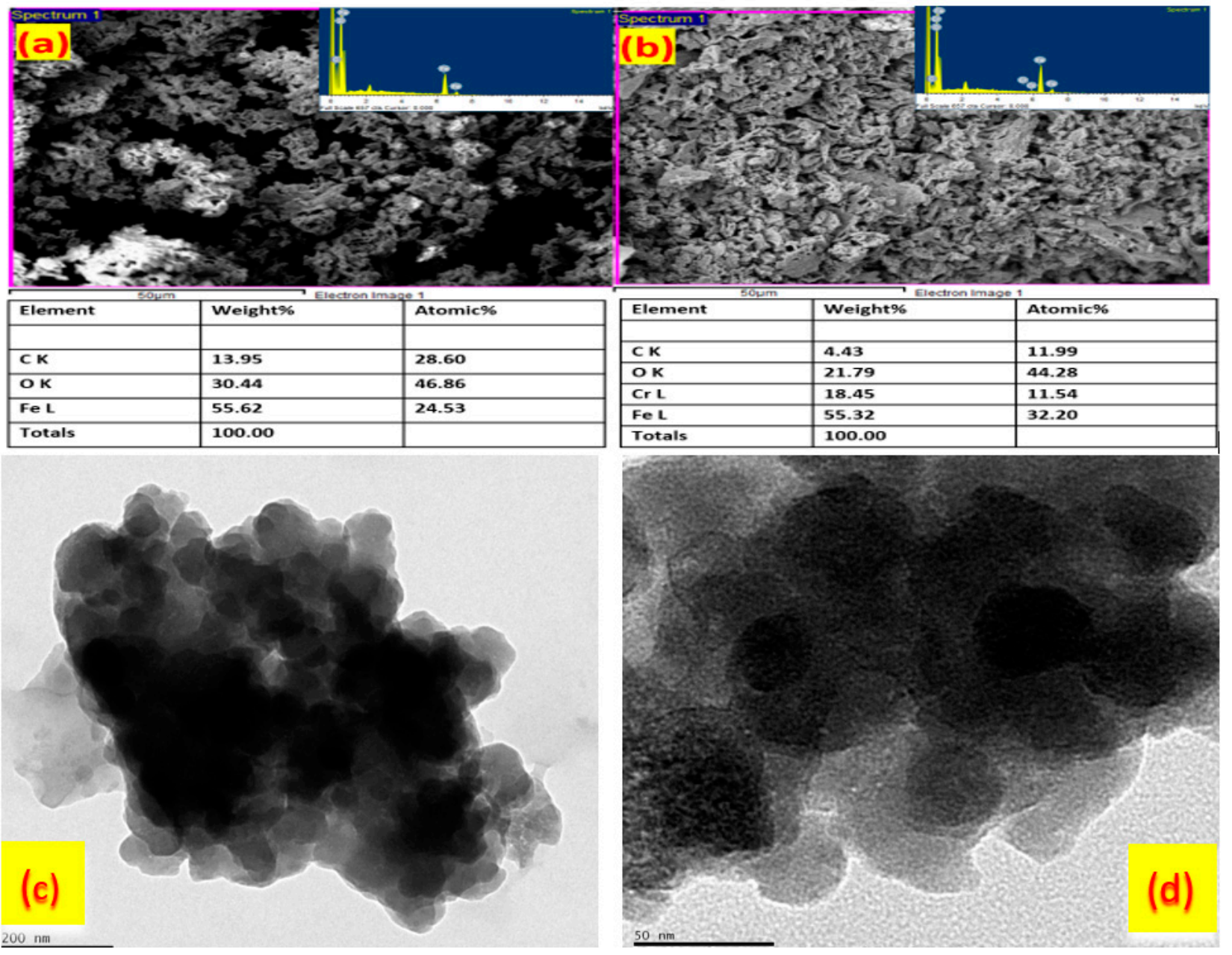

Figure 2. (a) SEM image shows the synthesized $\mathrm{Fe}_{3} \mathrm{O}_{4} \mathrm{NPs}$ using $\mathrm{B}$. amylolique faciens before $\mathrm{Cr}(\mathrm{VI})$ adsorption; (insert) EDX analysis of $\mathrm{Fe}_{3} \mathrm{O}_{4} \mathrm{NPs}$; (b) SEM analysis image of synthesized $\mathrm{Fe}_{3} \mathrm{O}_{4}$ NPs using B. amylolique faciens after $\mathrm{Cr}(\mathrm{VI})$ adsorption; EDX analysis of $\mathrm{Fe}_{3} \mathrm{O}_{4}$ NPs after $\mathrm{Cr}(\mathrm{VI})$ adsorption. TEM images of $\mathrm{Fe}_{3} \mathrm{O}_{4}$ nanoparticles showing the morphology of the nanoparticles at $200 \mathrm{~nm}(\mathbf{c})$ and $50 \mathrm{~nm}(\mathbf{d})$. 
BBD model for $\mathrm{Fe}_{3} \mathrm{O}_{4}$ NPs synthesis: The statistical analysis of BBD for $\mathrm{Fe}_{3} \mathrm{O}_{4}$ NPs yield by MSR5 strain exhibited a model F-value of 99.57, which implied the significance of the study. There was only a $0.01 \%$ chance that an F-value could have occurred due to noise. In addition, the values of "Prob $>F$ " less than 0.0500 indicated that the model terms B, C, $\mathrm{AB}, \mathrm{A} 2, \mathrm{~B}$, and $\mathrm{C} 2$ were significant.

The "Predicted R2" was estimated to be 0.878 , and it is in proximity with "adjusted $\mathrm{R} 2$ " 0.982 . A ratio greater than 4 is desirable for "adequate precision", and a ratio of 27.05 was obtained. The BBD model was used for navigating the design space.

Figure 3 shows the effect of the variables viz. $\mathrm{pH}$, temperature $\left({ }^{\circ} \mathrm{C}\right)$ and incubation time (h), where maximum $\mathrm{Fe}_{3} \mathrm{O}_{4} \mathrm{NPs}$ yield percentage (95\%) was achieved at $\mathrm{pH}$ 5.5, temperature $37^{\circ} \mathrm{C}$ and an incubation time of $70 \mathrm{~h}$. The perturbation plot showed maximum $\mathrm{Fe}_{3} \mathrm{O}_{4} \mathrm{NPs}$ yield at higher incubation time. With the increase in temperature, the decrease in the rate of formation of $\mathrm{Fe}_{3} \mathrm{O}_{4}$ NPs was witnessed. No formation of $\mathrm{Fe}_{3} \mathrm{O}_{4}$ NPs was observed when the temperature of a chemical reaction was higher than $45^{\circ} \mathrm{C}$. This was due to the fracture of biomolecules responsible for the reduction in Fe solution. Similarly, the rate of formation of $\mathrm{Fe}_{3} \mathrm{O}_{4} \mathrm{NPs}$ was found to increase with the increase in $\mathrm{pH}$. The increase in NP synthesis could be due to the formation of $\mathrm{Fe}(\mathrm{OH})_{3}$ in the initial part of the reaction, in the presence of $\mathrm{Fe}^{3+}$. When the $\mathrm{pH}$ was further increased, $\mathrm{Fe}(\mathrm{OH})_{2}$ was formed because of $\mathrm{Fe}^{2+}$ ions. As a result, $\mathrm{Fe}_{3} \mathrm{O}_{4} \mathrm{NPs}$ was found to be formed until the solution $\mathrm{pH}$ of 9.0 and then nucleation was found to occur. Likewise, an increase in the incubation time yielded a higher number of nanoparticles, with the highest yield at $120 \mathrm{~h}$.
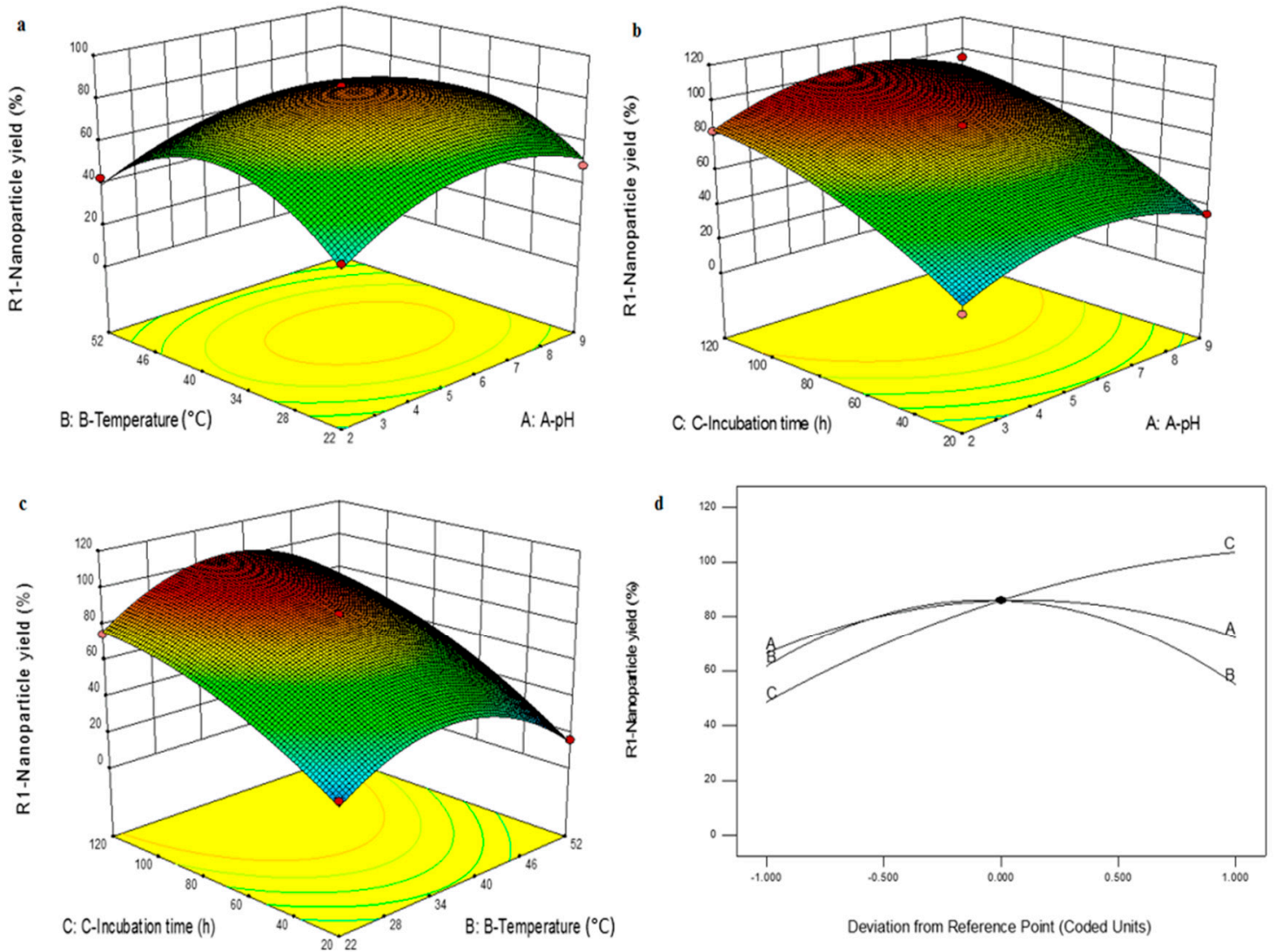

Figure 3. The 3D response surface plots showing the effects of interactions (a) effect of $\mathrm{pH}$ on $\mathrm{Cr}(\mathrm{VI})$ removal; (b) effect of temperature on removal of $\mathrm{Cr}(\mathrm{VI})$; (c) incubation time or contact time on $\mathrm{Cr}(\mathrm{VI})$ removal and (d) deviation from reference point (coded units). Note: A: effect of $\mathrm{pH}$; B: effect of temperature; $\mathrm{C}$ : incubation time (min). 


\subsection{Effect of Various Parameters on Cr(VI) Removal}

The effect of $\mathrm{pH}$ in the adsorption of $\mathrm{Cr}(\mathrm{IV})$ studies using $\mathrm{Fe}_{3} \mathrm{O}_{4} \mathrm{NPs}$ was investigated. In this analysis, varying ranges of $\mathrm{pH}$ from 1 to 9 were selected and it was observed that $\mathrm{Cr}(\mathrm{IV})$ adsorption rapidly increased with the decrease in $\mathrm{pH}$ from 3 . On the other hand, the adsorption capacity of $\mathrm{Cr}(\mathrm{IV})$ reduced with the increment in $\mathrm{pH}$ rising above $\mathrm{pH} 2$. From the investigation, the ideal $\mathrm{pH}$ range was identified to be $\mathrm{pH} 2$. The examination of the influence of adsorbent dosage during adsorption of $\mathrm{Cr}(\mathrm{IV})$ was conducted. With the increment in an adsorbent dose ranging from $0.25-1.0 \mathrm{~g} / \mathrm{L}$, the increase in removal rate of $\mathrm{Cr}(\mathrm{IV})$ using $\mathrm{Fe}_{3} \mathrm{O}_{4}$ NPs was witnessed. However, the adsorbent capacity of $\mathrm{Cr}(\mathrm{IV})$ using $\mathrm{Fe}_{3} \mathrm{O}_{4}$ NPs decreased from $93.802 \mathrm{mg} / \mathrm{g}$ to $40.83 \mathrm{mg} / \mathrm{g}$ when the dosage increased from $0.25 \mathrm{~g} / \mathrm{L}$ to $1.0 \mathrm{~g} / \mathrm{L}$ (Table S2).

The influence of contact time for the adsorption of $\mathrm{Cr}(\mathrm{IV})$ using $\mathrm{Fe}_{3} \mathrm{O}_{4} \mathrm{NPs}$ was briefly studied under 3 alternate $\mathrm{Cr}(\mathrm{IV})$ concentrations such as 25,50 and $100 \mathrm{mg} / \mathrm{L}$. The duration for this analysis was 0-600 min under the dose concentration of $0.5 \mathrm{~g} / \mathrm{L}$ at $27^{\circ} \mathrm{C}$ and agitation speed of $120 \mathrm{rpm}$. At the low concentration level of $50 \mathrm{mg} / \mathrm{L}$, the superior $\mathrm{Cr}(\mathrm{IV})$ adsorption happened within $480 \mathrm{~min}(97 \% \mathrm{Cr}(\mathrm{IV})$ removed). The quantity of $\mathrm{Cr}(\mathrm{IV})$ adsorbed using $\mathrm{Fe}_{3} \mathrm{O}_{4}$ NPs increased upon the increment in contact time. This is predominantly due to the presence of a large number of zones for adsorption and can be seen in Figure 4. Beyond the $480 \mathrm{~min}$, the state of equilibrium was achieved for the adsorption capacity of $\mathrm{Fe}_{3} \mathrm{O}_{4}$ NPs.

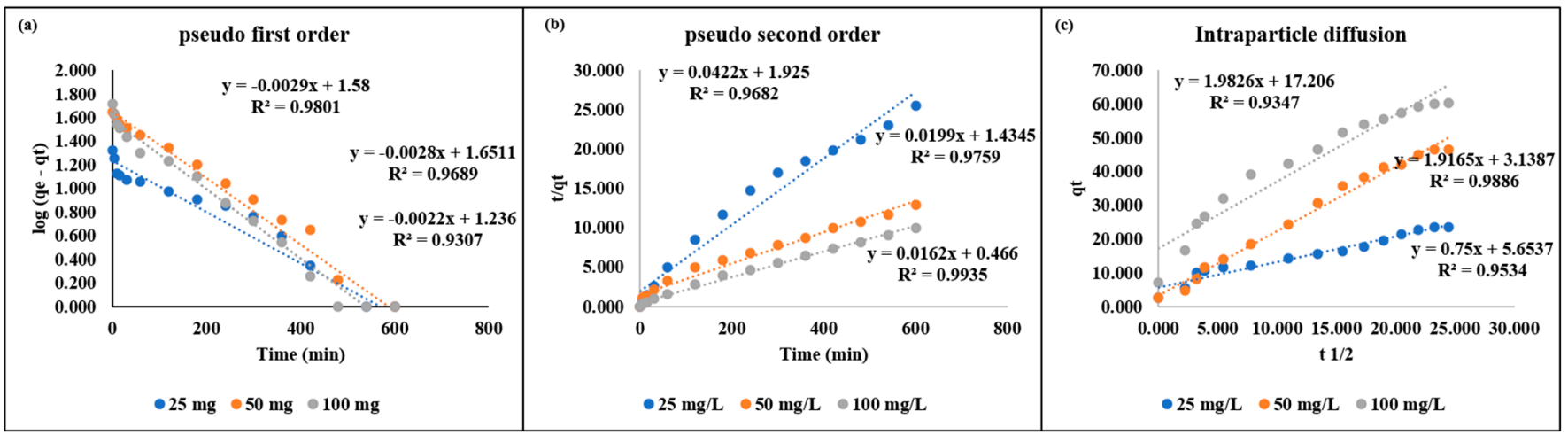

Figure 4. Kinetic modelling of the adsorption of $\mathrm{Cr}(\mathrm{VI})$ on $\mathrm{Fe}_{3} \mathrm{O}_{4} \mathrm{NPs}$ material, (a) pseudo-first-order kinetic plot, (b) pseudo-second-order kinetic plot, (c) intra-particle diffusion plot.

\subsection{Kinetic and Adsorption Isotherm Studies}

In the varying concentration of $\mathrm{Cr}$ (IV) from 25,50 and $100 \mathrm{mg} / \mathrm{L}$, the kinetic studies were carried out. The corresponding results are shown in Figure 5. The pseudo-first-order, pseudo-second-order and intra-particle diffusion models were adopted for the kinetic studies. The estimated outcomes are compiled in Table S3. The root means square error (RMSE) values are listed in Table S2. These values were used to evaluate the fitting of kinetic models. On comparing the 3 kinetic models, the pseudo-second-order model was identified to be desirable (Table S3). Using the Langmuir and Freundlich isotherm models, the adsorption isotherm for $\mathrm{Cr}(\mathrm{IV})$ was studied under different dose concentrations of 0.25-1.0 g/L (Figure 5). Upon the comparison, the Langmuir model was found to be an ideal fit, showing a monolayer surface adsorption. Obtained maximum capacity for the adsorption of Cr(IV) was found to be $98.03 \mathrm{mg} / \mathrm{g}$ and is presented in Table S4. This is significantly higher when compared to the recently reported literature. It is presented in Table S4 that pristine chitosan displayed $22.09 \mathrm{mg} / \mathrm{g}$ [57], the cyclodextrin-chitosan/GO had $61.31 \mathrm{mg} / \mathrm{g}$ [58], magnetic GO/chitosan composite showed $82.14 \mathrm{mg} / \mathrm{g}$ [59] and our biosynthesized $\mathrm{Fe}_{3} \mathrm{O}_{4}$ NPs showed enhanced adsorption $98.03 \mathrm{mg} / \mathrm{g}$. 


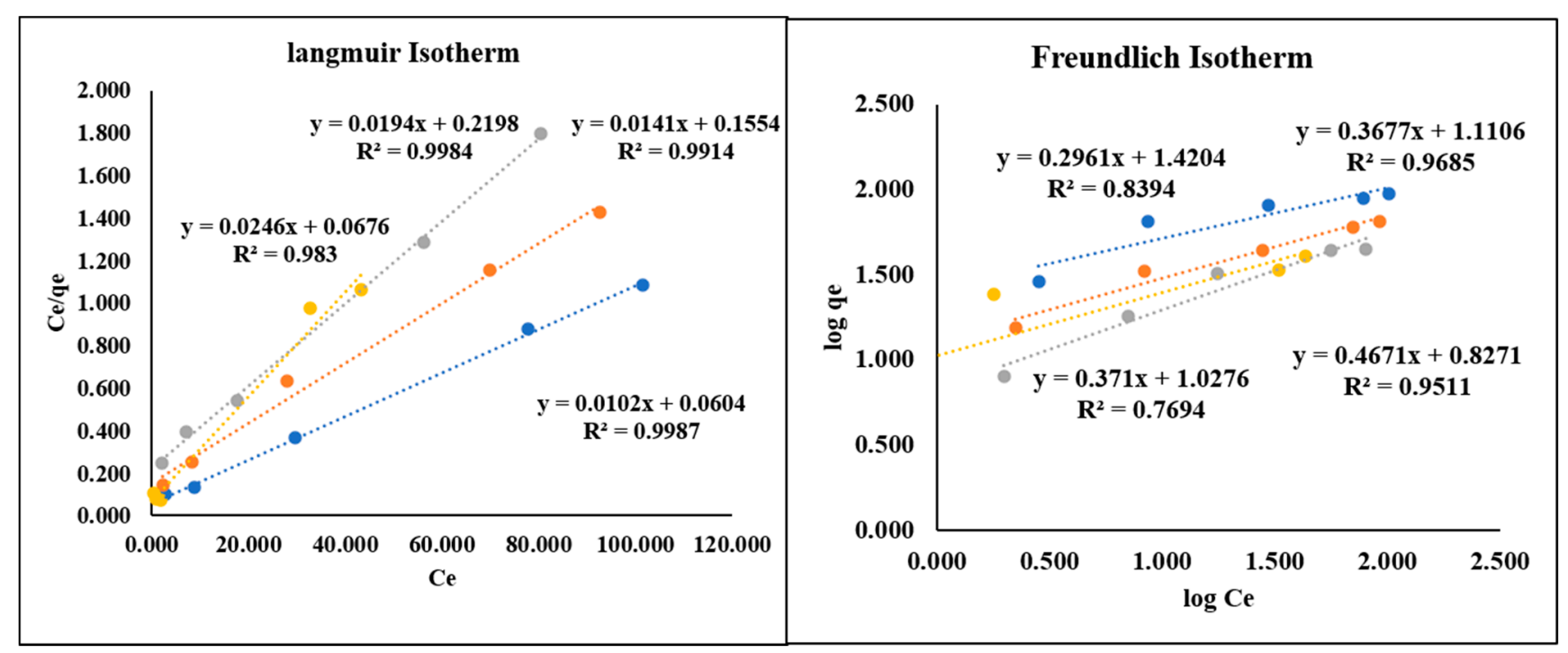

Figure 5. (a) Langmuir isotherm plot, (b) Freundlich isotherm plot for removal of $\mathrm{Cr}(\mathrm{VI})$ using $\mathrm{Fe}_{3} \mathrm{O}_{4} \mathrm{NPs}_{\text {material. }}$

\subsection{Adsorption Regeneration and Reuse}

The $\mathrm{Cr}(\mathrm{IV})$ desorption investigation using $\mathrm{Fe}_{3} \mathrm{O}_{4} \mathrm{NPs}$ was performed using $1 \mathrm{~mol} / \mathrm{L}$ $\mathrm{NaOH}$ conditions. The identical conditions were adopted for the successive adsorption investigation, and subsequently the adsorption capacity was examined. As an inference from studies, it was observed that the $\mathrm{Fe}_{3} \mathrm{O}_{4}$ NPs adsorbed $\mathrm{Cr}(\mathrm{IV})$ efficiently from the aquatic solution for the five cycles with a negligible decrease in adsorption capacity. The $\mathrm{Fe}_{3} \mathrm{O}_{4}$ nanostructures displayed an impressive $73 \%$ removal efficiency even after 5 cycles of investigation. From $92 \%$ for the first cycle, they decreased only slightly to $73 \%$ for the fifth cycle. They are shown in Figure 6. From previous studies it has been observed that there is a loss of adsorption capacity of iron oxide. These obtained results evidently indicate that the $\mathrm{Fe}_{3} \mathrm{O}_{4}$ NPs are extremely potent for the low-cost removal of $\mathrm{Cr}(\mathrm{IV})$ ions from the polluted water. There have been suggestions that over multiple reactions, the nanoparticles lose their stability and tend to aggregate, which leads them to lose their magnetic properties, hence causing reduction in reusability. Surface modifications help to increase the stability a great deal and also, as observed in our study modification by exo-polysaccharides, helped to increase the stability compared to many other studies conducted before. However further work is required to increase the stability of these nanoparticles even further, so as to strengthen them and increase their reusability [60-64].

\subsection{Cytotoxicity Studies on A549 Cell Line}

The cell viability and toxicity investigations were conducted on A549 cells. The MTT assay on $\mathrm{A} 549$ was performed using $\mathrm{Fe}_{3} \mathrm{O}_{4} \mathrm{NPs}$ (cytotoxicity studies). As presented in Figure S3, the effect of $\mathrm{Fe}_{3} \mathrm{O}_{4} \mathrm{NPs}$ under the varying concentrations of $10-200 \mu \mathrm{g} / \mathrm{L}$ on the A549 cell growth was investigated. Upon the increase in the concentration of $\mathrm{Fe}_{3} \mathrm{O}_{4} \mathrm{NPs}$, the $\%$ of cell death increased as well. The major alterations in the composition of cells were observed when effectively compared to control cells. The prepared $\mathrm{Fe}_{3} \mathrm{O}_{4} \mathrm{NPs}$ inhibition concentration $\left(\mathrm{IC}_{50}\right)$ was estimated to be $50 \mu \mathrm{g} / \mathrm{L}$ for the $\mathrm{A} 549$ cell lines. Therefore, it can be understood that the toxicity of $\mathrm{Fe}_{3} \mathrm{O}_{4}$ NPs depends on their size, form and charge. 


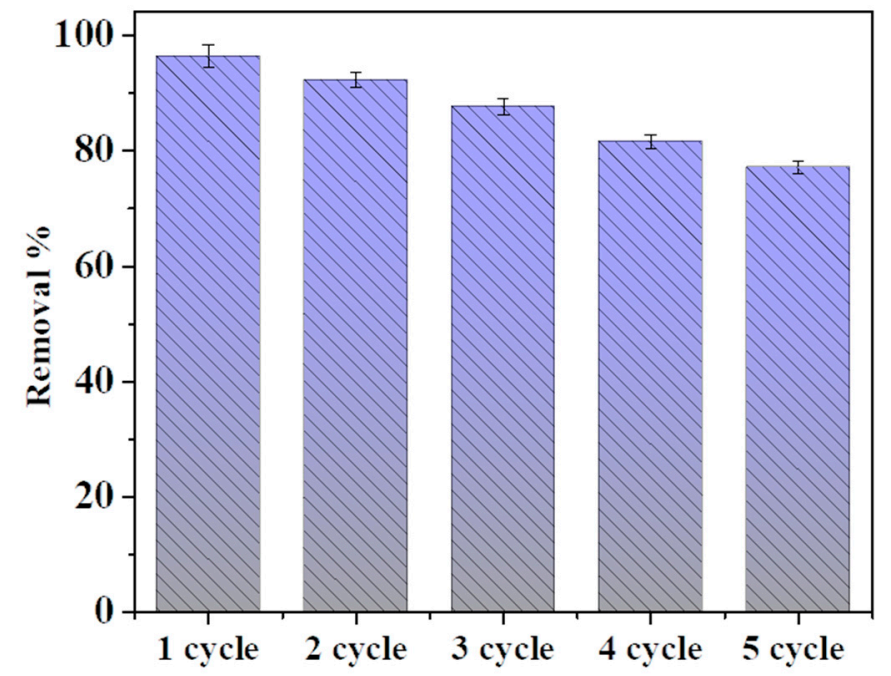

Figure 6. Regeneration study of $\mathrm{Fe}_{3} \mathrm{O}_{4} \mathrm{NPs}$ material.

\section{Conclusions}

The E. faecalis_RMSN6 showed the ability to synthesize iron oxide nanoparticles by extracellular supernatant. The E. faecalis_RMSN6 synthesized the metal nanoparticles extracellularly at a rapid rate. In such a way, we synthesized the $\mathrm{Fe}_{3} \mathrm{O}_{4}$ nanoparticles for the heavy metal removal and cytotoxicity analysis. The UV-Visible spectroscopy, FT-IR spectroscopy and XRD pattern vindicate the efficacy of E. faecalis_RMSN6 to synthesize $\mathrm{Fe}_{3} \mathrm{O}_{4}$ nanoparticles extracellularly. The size of $\mathrm{Fe}_{3} \mathrm{O}_{4} \mathrm{NPs}$ was determined using SEM-EDX and DLS, and is in the range of $15-20 \mathrm{~nm}$. The $\mathrm{Fe}_{3} \mathrm{O}_{4}$ NPs can potentially be utilized as alternate adsorbents to the traditional adsorbents for the efficient removal of heavy metal ions from polluted water.

This research investigation indicates that the adsorption equilibrium was achieved under $480 \mathrm{~min}$. This shows the adsorption was mainly dependent on initial Cr(VI) concentration and $\mathrm{pH}$. Ultimately, the highest level of $\mathrm{Cr}(\mathrm{VI})$ adsorption was observed at $\mathrm{pH} 2$ under room temperature conditions, and adsorption capacity of the nanoparticles was found to be $98.03 \mathrm{mg} / \mathrm{g}$. After 5 cycles of repeated experimentation, the nanoparticles retained up to $73 \%$ of their efficiency of chromium removal. The Langmuir isotherm model was the best fit compared to the Freundlich model. In vitro studies have shown synthesized $\mathrm{Fe}_{3} \mathrm{O}_{4}$ NPs to have elevated cytotoxicity activity against cell lines, suggesting the future therapeutic application of the nanoparticles. Overall, this analysis indicates the dual advantage of the biosynthesized $\mathrm{Fe}_{3} \mathrm{O}_{4}$ NPs, i.e., nanoparticles that could be used for the removal of chemicals or dyes from wastewater and possible use in biomedical applications.

Supplementary Materials: The following are available online at https:/ /www.mdpi.com/article/10 $.3390 /$ nano11123290/s1. Figure S1: Neighbor- joining phylogenetic tree of 16s rRNA gene sequence of bacterial strain RMSN6 and most closely related species; Figure S2. Assembled Sequence for Sample RMSN6; Figure S3. Effect of biosynthesized $\mathrm{Fe}_{3} \mathrm{O}_{4} \mathrm{NPs}$ on A549 lung carcinoma epithelial cells at 50-250 $\mu \mathrm{g} / \mathrm{L}$ for $24 \mathrm{~h}$; Table S1. Primer Details; Table S2: Isotherm model regression constants for different experimental conditions; Table S3: Kinetics parameters for the adsorption of $\mathrm{Cr}(\mathrm{VI})$ by $\mathrm{Fe}_{3} \mathrm{O}_{4} \mathrm{NPs}$ material based on different concentrations; Table S4: Adsorption comparison of $\mathrm{Fe}_{3} \mathrm{O}_{4} \mathrm{NPs}$ and reported studies on adsorbents for Cr(VI); PCR Protocol; References [65-74] are cited in the supplementary materials. 
Author Contributions: Conceptualization, M.S.S. and E.S.; methodology, M.S.S., E.S., R.B., S.D., N.C. and S.V.; software, M.S.S., R.B. and E.S.; validation, M.S.S., R.B. and S.D.; formal analysis, M.S.S. and S.D.; investigation, M.S.S. and S.D.; resources, M.S.S. and E.S.; data curation, M.S.S., R.B. and S.V.; writing-original draft preparation, M.S.S., E.S., R.B. and S.D.; writing-review and editing, M.S.S., S.D., R.B., E.S., N.C. and S.V.; visualization, E.S., S.V. and N.C.; supervision, E.S.; project administration, M.S.S. and E.S.; funding acquisition, M.S.S. All authors have read and agreed to the published version of the manuscript.

Funding: This research received no external funding.

Institutional Review Board Statement: Not applicable.

Informed Consent Statement: Not applicable.

Data Availability Statement: Not applicable.

Acknowledgments: S. Melvin S Samuel is thankful to IIT Kharagpur for providing laboratory facilities and financial assistance. E.S express thanks to the Department of Genetic Engineering and SRMIST for providing an excellent facility for this work.

Conflicts of Interest: The authors declare that they have no conflict of interest.

\section{References}

1. Farzin, A.; Etesami, S.A.; Quint, J.; Memic, A.; Tamayol, A. Magnetic nanoparticles in cancer therapy and diagnosis. Adv. Healthc. Mater. 2020, 9, e1901058. [CrossRef]

2. Jose, J.; Kumar, R.; Harilal, S.; Mathew, G.E.; Prabhu, A.; Uddin, M.S.; Aleya, L.; Kim, H.; Mathew, B. Magnetic nanoparticles for hyperthermia in cancer treatment: An emerging tool. Environ. Sci. Pollut. Res. 2020, 27, 19214-19225. [CrossRef]

3. Stueber, D.D.; Villanova, J.; Aponte, I.; Xiao, Z.; Colvin, V.L. Magnetic nanoparticles in biology and medicine: Past, present, and future trends. Pharmaceutics 2021, 13, 943. [CrossRef]

4. Naha, P.C.; Hsu, J.C.; Kim, J.; Shah, S.; Bouché, M.; Si-Mohamed, S.; Rosario-Berrios, D.N.; Douek, P.; Hajfathalian, M.; Yasini, P. Dextran-coated cerium oxide nanoparticles: A computed tomography contrast agent for imaging the gastrointestinal tract and inflammatory bowel disease. ACS Nano 2020, 14, 10187-10197. [CrossRef]

5. Koudan, E.V.; Zharkov, M.N.; Gerasimov, M.V.; Karshieva, S.S.; Shirshova, A.D.; Chrishtop, V.V.; Kasyanov, V.A.; Levin, A.A.; Parfenov, V.A.; Karalkin, P.A. Magnetic patterning of tissue spheroids using polymer microcapsules containing iron oxide nanoparticles. ACS Biomater. Sci. Eng. 2021, 7, 5206-5214. [CrossRef]

6. Arias, L.S.; Pessan, J.P.; Vieira, A.P.M.; Lima, T.M.T.d.; Delbem, A.C.B.; Monteiro, D.R. Iron oxide nanoparticles for biomedical applications: A perspective on synthesis, drugs, antimicrobial activity, and toxicity. Antibiotics 2018, 7, 46. [CrossRef]

7. Miranda, M.S.; Rodrigues, M.T.; Domingues, R.M.; Costa, R.R.; Paz, E.; Rodríguez-Abreu, C.; Freitas, P.; Almeida, B.G.; Carvalho, M.A.; Gonçalves, C. Development of inhalable superparamagnetic iron oxide nanoparticles (SPIONs) in microparticulate system for antituberculosis drug delivery. Adv. Healthc. Mater. 2018, 7, 1800124. [CrossRef]

8. Jabir, M.S.; Nayef, U.M.; Abdulkadhim, W.K.; Taqi, Z.J.; Sulaiman, G.M.; Sahib, U.I.; Al-Shammari, A.M.; Wu, Y.-J.; El-Shazly, M.; $\mathrm{Su}$, C.C. Fe $3 \mathrm{O} 4$ nanoparticles capped with PEG induce apoptosis in breast cancer AMJ13 cells via mitochondrial damage and reduction of NF-kB translocation. J. Inorg. Organomet. Polym. Mater. 2021, 31, 1241-1259. [CrossRef]

9. Zhang, T.; Wang, Z.; Xiang, H.; Xu, X.; Zou, J.; Lu, C. Biocompatible superparamagnetic europium-doped iron oxide nanoparticle clusters as multifunctional nanoprobes for multimodal in vivo imaging. ACS Appl. Mater. Interfaces 2021, 13, 33850-33861. [CrossRef]

10. Yang, X.; Liu, L.; Zhang, M.; Tan, W.; Qiu, G.; Zheng, L. Improved removal capacity of magnetite for Cr(IV) by electrochemical reduction. J. Hazard. Mater. 2019, 374, 26-34. [CrossRef]

11. Nuzhina, J.V.; Shtil, A.A.; Prilepskii, A.Y.; Vinogradov, V.V. Preclinical evaluation and clinical translation of magnetite-based nanomedicines. J. Drug Deliv. Sci. Technol. 2019, 54, 101282. [CrossRef]

12. Lin, K.; Wang, L.; Tian, F.; Du, K.; Chang, Y.; Han, L.; Yao, P. A facile and controllable protocol for simultaneous synthesis of magnetite nanoparticles and luminescent carbon dots. J. Alloys Compd. 2018, 769, 360-366. [CrossRef]

13. Mattei, J.-G.; Grammatikopoulos, P.; Zhao, J.; Singh, V.; Vernieres, J.; Steinhauer, S.; Porkovich, A.; Danielson, E.; Nordlund, K.; Djurabekova, F. Gas-phase synthesis of trimetallic nanoparticles. Chem. Mater. 2019, 31, 2151-2163. [CrossRef]

14. Niculescu, A.-G.; Chircov, C.; Grumezescu, A.M. Magnetite nanoparticles: Synthesis methods-a comparative review. Methods 2019, 31, 2151-2163. [CrossRef]

15. Wang, L.; Dong, L.; Li, L.; Weng, Z.; Xu, H.; Yu, M.; Wang, Z. Fabrication of periodically micropatterned magnetite nanoparticles by laser-interference-controlled electrodeposition. J. Mater. Sci. 2018, 53, 3239-3249. [CrossRef]

16. Darezereshki, E.; Darban, A.K.; Abdollahy, M.; Jamshidi, A. Synthesis of magnetite nanoparticles from iron ore tailings using a novel reduction-precipitation method. J. Alloys Compd. 2018, 749, 336-343. [CrossRef]

17. Senthilkumar, P.; Surendran, L.; Sudhagar, B.; DS, R.S.K.; Bupesh, G. Hydrothermal assisted Eichhornia crassipes mediated synthesis of magnetite nanoparticles $\left(\mathrm{E}^{-} \mathrm{Fe}_{3} \mathrm{O}_{4}\right)$ and its antibiofilm activity. Mater. Res. Express 2019, 6, 095405. 
18. Kim, Y.; Roh, Y. Effects of microbial growth conditions on synthesis of magnetite nanoparticles using indigenous Fe (III)-reducing bacteria. Minerals 2018, 8, 212. [CrossRef]

19. Khosravi, M.; Nouri, M.; Mohammadi, A.; Mosavari, N.; Constable, P. Preparation of immunomagnetic beads coupled with a rhodamine hydrazine immunosensor for the detection of Mycobacterium avium subspecies paratuberculosis in bovine feces, milk, and colostrum. J. Dairy Sci. 2021, 104, 6944-6960. [CrossRef]

20. Perez-Gonzalez, T.; Jimenez-Lopez, C.; Neal, A.L.; Rull-Perez, F.; Rodriguez-Navarro, A.; Fernandez-Vivas, A.; Iañez-Pareja, E. Magnetite biomineralization induced by Shewanellaoneidensis. Geochim. Cosmochim. Acta 2010, 74, 967-979. [CrossRef]

21. Klueglein, N.; Lösekann-Behrens, T.; Obst, M.; Behrens, S.; Appel, E.; Kappler, A. Magnetite formation by the novel Fe (III)reducing Geothrixfermentans strain HradG1 isolated from a hydrocarbon-contaminated sediment with increased magnetic susceptibility. Geomicrobiol. J. 2013, 30, 863-873. [CrossRef]

22. Duruibe, J.O.; Ogwuegbu, M.; Egwurugwu, J. Heavy metal pollution and human biotoxic effects. Int. J. Phys. Sci. 2007, 2, 112-118.

23. Balaji, R.; Renganathan, V.; Chen, S.M.; Singh, V. Selective and High-Performance Electrochemical Sensor for Cadmium Ions Based on Intimate Binary Spinel $\mathrm{CoMn}_{2} \mathrm{O}_{4}$ Nanostructures. ChemistrySelect 2019, 4, 13123-13130. [CrossRef]

24. Ahmad, M.; Manzoor, K.; Ikram, S. Versatile nature of hetero-chitosan based derivatives as biodegradable adsorbent for heavy metal ions; a review. Int. J. Biol. Macromol. 2017, 105, 190-203. [CrossRef] [PubMed]

25. Su, X.; Kushima, A.; Halliday, C.; Zhou, J.; Li, J.; Hatton, T.A. Electrochemically-mediated selective capture of heavy metal chromium and arsenic oxyanions from water. Nat. Commun. 2018, 9, 4701. [CrossRef]

26. Wu, D.; Sui, Y.; He, S.; Wang, X.; Li, C.; Kong, H. Removal of trivalent chromium from aqueous solution by zeolite synthesized from coal fly ash. J. Hazard. Mater. 2008, 155, 415-423. [CrossRef]

27. Elangovan, R.; Philip, L.; Chandraraj, K. Biosorption of hexavalent and trivalent chromium by palm flower (Borassus aethiopum). Chem. Eng. J. 2008, 141, 99-111. [CrossRef]

28. DesMarias, T.L.; Costa, M. Mechanisms of chromium-induced toxicity. Curr. Opin. Toxicol. 2019, 14, 1-7. [CrossRef]

29. He, X.; Li, P. Surface water pollution in the middle Chinese Loess Plateau with special focus on hexavalent chromium (Cr 6+): Occurrence, sources and health risks. Expo. Health 2020, 12, 385-401. [CrossRef]

30. Tseng, C.-H.; Lei, C.; Chen, Y.-C. Evaluating the health costs of oral hexavalent chromium exposure from water pollution: A case study in Taiwan. J. Clean. Prod. 2018, 172, 819-826. [CrossRef]

31. Owlad, M.; Aroua, M.K.; Daud, W.A.W.; Baroutian, S. Removal of hexavalent chromium-contaminated water and wastewater: A review. Water Air Soil Pollut. 2009, 200, 59-77. [CrossRef]

32. Long, F.-L.; Niu, C.-G.; Tang, N.; Guo, H.; Li, Z.-W.; Yang, Y.-Y.; Lin, L.-S. Highly efficient removal of hexavalent chromium from aqueous solution by calcined Mg/Al-layered double hydroxides/polyaniline composites. Chem. Eng. J. 2021, $404,127084$. [CrossRef]

33. Daradmare, S.; Xia, M.; Kim, J.; Park, B.J. Metal-organic frameworks/alginate composite beads as effective adsorbents for the removal of hexavalent chromium from aqueous solution. Chemosphere 2021, 270, 129487. [CrossRef]

34. Ahmad, W.; Qaiser, S.; Ullah, R.; Mohamed Jan, B.; Karakassides, M.A.; Salmas, C.E.; Kenanakis, G.; Ikram, R. Utilization of Tires Waste-Derived Magnetic-Activated Carbon for the Removal of Hexavalent Chromium from Wastewater. Materials 2021, 14, 34. [CrossRef]

35. Duan, W.; Chen, G.; Chen, C.; Sanghvi, R.; Iddya, A.; Walker, S.; Liu, H.; Ronen, A.; Jassby, D. Electrochemical removal of hexavalent chromium using electrically conducting carbon nanotube/polymer composite ultrafiltration membranes. J. Membr. Sci. 2017, 531, 160-171. [CrossRef]

36. Jiang, Y.; Liu, Z.; Zeng, G.; Liu, Y.; Shao, B.; Li, Z.; Liu, Y.; Zhang, W.; He, Q. Polyaniline-based adsorbents for removal of hexavalent chromium from aqueous solution: A mini review. Environ. Sci. Pollut. Res. 2018, 25, 6158-6174. [CrossRef]

37. Neagu, V.; Mikhalovsky, S. Removal of hexavalent chromium by new quaternized crosslinked poly (4-vinylpyridines). J. Hazard. Mater. 2010, 183, 533-540. [CrossRef]

38. Kumar, A.S.K.; Kakan, S.S.; Rajesh, N. A novel amine impregnated graphene oxide adsorbent for the removal of hexavalent chromium. Chem. Eng. J. 2013, 230, 328-337. [CrossRef]

39. Vilardi, G.; Ochando-Pulido, J.M.; Verdone, N.; Stoller, M.; Di Palma, L. On the removal of hexavalent chromium by olive stones coated by iron-based nanoparticles: Equilibrium study and chromium recovery. J. Clean. Prod. 2018, 190, 200-210. [CrossRef]

40. Cheng, S.; Pan, X.; Zhang, C.; Lin, X.; Zhuang, Q.; Jiao, Y.; Dong, W.; Qi, X. UV-assisted ultrafast construction of robust $\mathrm{Fe}_{3} \mathrm{O}_{4}$ / polydopamine/Ag Fenton-like catalysts for highly efficient micropollutant decomposition. Sci. Total. Environ. 2021, 151182. [CrossRef]

41. Nizamuddin, S.; Siddiqui, M.T.H.; Mubarak, N.M.; Baloch, H.A.; Abdullah, E.C.; Mazari, S.A.; Griffin, G.J.; Srinivasan, M.P.; Tanksale, A. Iron oxide nanomaterials for the removal of heavy metals and dyes from wastewater. Nanoscale Mater. Water Purif. 2019, 2019, 447-472.

42. Qi, X.; Tong, X.; Pan, W.; Zeng, Q.; You, S.; Shen, J. Recent advances in polysaccharide-based adsorbents for wastewater treatment. J. Clean. Prod. 2021, 315, 128221. [CrossRef]

43. Yang, Q.; Wang, H.; Li, F.; Dang, Z.; Zhang, L. Rapid and efficient removal of Cr(IV) by a core-shell magnetic mesoporous polydopamine nanocomposite: Roles of the mesoporous structure and redox-active functional groups. J. Mater. Chem. A 2021, 9 , 13306-13319. [CrossRef] 
44. Cheng, S.; Zhang, C.; Li, J.; Pan, X.; Zhai, X.; Jiao, Y.; Li, Y.; Dong, W.; Qi, X. Highly efficient removal of antibiotic from biomedical wastewater using Fenton-like catalyst magnetic pullulan hydrogels. Carbohydr. Polym. 2021, 262, 117951. [CrossRef] [PubMed]

45. Wang, Z.; Yang, H.C.; He, F.; Peng, S.; Li, Y.; Shao, L.; Darling, S.B. Mussel-inspired surface engineering for water-remediation materials. Matter 2019, 1, 115-155. [CrossRef]

46. Donot, F.; Fontana, A.; Baccou, J.; Schorr-Galindo, S. Microbial exopolysaccharides: Main examples of synthesis, excretion, genetics and extraction. Carbohydr. Polym. 2012, 87, 951-962. [CrossRef]

47. Rana, S.; Upadhyay, L.S.B. Microbial exopolysaccharides: Synthesis pathways, types and their commercial applications. Int. J. Biol. Macromol. 2020, 157, 577-583. [CrossRef]

48. Yildiz, H.; Karatas, N. Microbial exopolysaccharides: Resources and bioactive properties. Process. Biochem. 2018, 72, 41-46. [CrossRef]

49. Madhuri, K.; Prabhakar, K.V. Microbial exopolysaccharides: Biosynthesis and potential applications. Orient. J. Chem. 2014, 30, 1401. [CrossRef]

50. Velusamy, P.; Awad, Y.; Abd El-Azeem, S.; Ok, Y. Screening of heavy metal resistant bacteria isolated from hydrocarbon contaminated soil in Korea. J. Agric. Life Environ. Sci. 2011, 23, 40-43.

51. Samuel, M.S.; Chidambaram, R. Hexavalent chromium biosorption studies using Penicillium griseofulvum MSR1 a novel isolate from tannery effluent site: Box-Behnken optimization, equilibrium, kinetics and thermodynamic studies. J. Taiwan Inst. Chem. Eng. 2015, 49, 156-164.

52. Samuel, M.S.; Selvarajan, E.; Subramaniam, K.; Mathimani, T.; Seethappan, S.; Pugazhendhi, A. Synthesized $\beta$-cyclodextrin modified graphene oxide ( $\beta$-CD-GO) composite for adsorption of cadmium and their toxicity profile in cervical cancer (HeLa) cell lines. Process. Biochem. 2020, 93, 28-35. [CrossRef]

53. Chidambaram, R. Isotherm modelling, kinetic study and optimization of batch parameters using response surface methodology for effective removal of Cr(IV) using fungal biomass. PLoS ONE 2015, 10, e0116884.

54. Abdeen, M.; Sabry, S.; Ghozlan, H.; El-Gendy, A.A.; Carpenter, E.E. Microbial-physical synthesis of $\mathrm{Fe}$ and $\mathrm{Fe}_{3} \mathrm{O}_{4} \mathrm{magnetic}$ nanoparticles using Aspergillus niger YESM1 and supercritical condition of ethanol. J. Nanomater. 2016, 2016, 9174891. [CrossRef]

55. Razak, M.N.A.; Ibrahim, M.F.; Yee, P.L.; Hassan, M.A.; Abd-Aziz, S. Utilization of oil palm decanter cake for cellulase and polyoses production. Biotechnol. Bioprocess Eng. 2012, 17, 547-555. [CrossRef]

56. Asuha, S.; Zhao, S.; Wu, H.; Song, L.; Tegus, O. One step synthesis of maghemite nanoparticles by direct thermal decomposition of Fe-urea complex and their properties. J. Alloys Compd. 2009, 472, L23-L25. [CrossRef]

57. Aydın, Y.A.; Aksoy, N.D. Adsorption of chromium on chitosan: Optimization, kinetics and thermodynamics. Chem. Eng. J. 2009, 151, 188-194. [CrossRef]

58. Li, L.; Fan, L.; Sun, M.; Qiu, H.; Li, X.; Duan, H.; Luo, C. Adsorbent for chromium removal based on graphene oxide functionalized with magnetic cyclodextrin-chitosan. Colloids Surf. B Biointerfaces 2013, 107, 76-83. [CrossRef] [PubMed]

59. Samuel, M.S.; Bhattacharya, J.; Raj, S.; Santhanam, N.; Singh, H.; Singh, N.P. Efficient removal of Chromium (VI) from aqueous solution using chitosan grafted graphene oxide (CS-GO) nanocomposite. Int. J. Biol. Macromol. 2019, 121, 285-292. [CrossRef]

60. Samuel, M.S.; Datta, S.; Khandge, R.S.; Selvarajan, E. A state of the art review on characterization of heavy metal binding metallothioneins proteins and their widespread applications. Sci. Total Environ. 2021, 775, 145829. [CrossRef]

61. Samuel, M.S.; Selvarajan, E.; Chidambaram, R.; Patel, H.; Brindhadevi, K. Clean approach for chromium removal in aqueous environments and role of nanomaterials in bioremediation: Present research and future perspective. Chemosphere 2021, 284, 131368. [CrossRef] [PubMed]

62. Samuel, M.S.; Shah, S.S.; Bhattacharya, J.; Subramaniam, K.; Pradeep Singh, N.D. Adsorption of Pb(II) from aqueous solution using a magnetic chitosan/graphene oxide composite and its toxicity studies. Int. J. Biol. Macromol. 2018, 303, 225-228. [CrossRef] [PubMed]

63. Bahador, F.; Foroutan, R.; Esmaeili, H.; Ramavandi, B. Enhancement of the chromium removal behavior of Moringa oleifera activated carbon by chitosan and iron oxide nanoparticles from water. Carbohydr. Polym. 2021, 251, 117085. [CrossRef] [PubMed]

64. Samuel, M.S.; Subramaniyan, V.; Bhattacharya, J.; Chidambaram, R.; Qureshi, T.; Pradeep Singh, N.D. Ultrasonic-assisted synthesis of graphene oxide-fungal hyphae: An efficient and reclaimable adsorbent for chromium(VI) removal from aqueous solution. Ultrason. Sonochem. 2018, 48, 412-417. [CrossRef] [PubMed]

65. Hu, X.-j.; Wang, J.-s.; Liu, Y.-g.; Li, X.; Zeng, G.-m.; Bao, Z.-l.; Zeng, X.-x.; Chen, A.-w.; Long, F. Adsorption of chromium (VI) by ethylenediamine-modified cross-linked magnetic chitosan resin: isotherms, kinetics and thermodynamics. J. Hazard. Mater. 2011, 185, 306-314. [CrossRef] [PubMed]

66. Chidambaram, R. Isotherm modelling, kinetic study and optimization of batch parameters using response surface methodology for effective removal of Cr (VI) using fungal biomass. PloS ONE 2015, 10, e0116884.

67. Tianwei, T.; Xiaojing, H.; Weixia, D. Adsorption behaviour of metal ions on imprinted chitosan resin. J. Chem. Technol. Biotechnol. Int. Res. Process. Environ. Clean Technol. 2001, 76, 191-195. [CrossRef]

68. Thinh, N.N.; Hanh, P.T.B.; Hoang, T.V.; Hoang, V.D.; Van Khoi, N.; Dai Lam, T. Magnetic chitosan nanoparticles for removal of Cr (VI) from aqueous solution. Mater. Sci. Eng. C 2013, 33, 1214-1218. [CrossRef]

69. Samuel, M.S.; Subramaniyan, V.; Bhattacharya, J.; Parthiban, C.; Chand, S.; Singh, N.P. A GO-CS@ MOF [Zn (BDC)(DMF)] material for the adsorption of chromium (VI) ions from aqueous solution. Compos. Part B Eng. 2018, 152, 116-125. [CrossRef] 
70. Badruddoza, A.Z.M.; Shawon, Z.B.Z.; Tay, W.J.D.; Hidajat, K.; Uddin, M.S. Fe3O4/cyclodextrin polymer nanocomposites for selective heavy metals removal from industrial wastewater. Carbohydr. Polym. 2013, 91, 322-332. [CrossRef]

71. Wen, T.; Fan, Q.; Tan, X.; Chen, Y.; Chen, C.; Xu, A.; Wang, X. A core-shell structure of polyaniline coated protonic titanate nanobelt composites for both Cr (VI) and humic acid removal. Polym. Chem. 2016, 7, 785-794. [CrossRef]

72. Wang, J.; Wang, X.; Zhao, G.; Song, G.; Chen, D.; Chen, H.; Xie, J.; Hayat, T.; Alsaedi, A.; Wang, X. Polyvinylpyrrolidone and polyacrylamide intercalated molybdenum disulfide as adsorbents for enhanced removal of chromium (VI) from aqueous solutions. Chem. Eng. J. 2018, 334, 569-578. [CrossRef]

73. Samuel, M.S.; Shah, S.S.; Subramaniyan, V.; Qureshi, T.; Bhattacharya, J.; Singh, N.P. Preparation of graphene oxide/chitosan/ferrite nanocomposite for Chromium (VI) removal from aqueous solution. Int. J. Biol. Macromol. 2018, 119, 540-547. [CrossRef] [PubMed]

74. Wen, T.; Wang, J.; Yu, S.; Chen, Z.; Hayat, T.; Wang, X. Magnetic porous carbonaceous material produced from tea waste for efficient removal of As (V), Cr (VI), humic acid, and dyes. ACS Sustain. Chem. Eng. 2017, 5, 4371-4380. [CrossRef] 